\title{
STRUCTURE DETERMINATION, VIBRATIONAL BANDS AND CHEMICAL SHIFT ASSIGNMENTS OF 3-(4-(3-(2,5-DIMETHYLPHENYL)-3- METHYLCYCLOBUTYL)THIAZOL-2-YL)-2-(O-TOLYL)THIAZOLIDIN-4-ONE: A COMBINED EXPERIMENTAL AND QUANTUM CHEMICAL DENSITY-FUNCTIONAL THEORY STUDIES
}

\author{
Fatih Şen \\ Yozgat Bozok University, Sorgun Vocational School, Department of Opticianry, Yozgat, Turkey \\ fatihsen55@gmail.com
}

This paper report is an analysis of the title compound by means of X-ray crystallography, FT-IR, NMR and DFT calculations, in the context of structural and spectral characterization. The crystal and molecular structures of the compound were determined by single-crystal X-ray diffraction (SCXRD). Fourier Transform Infrared (FTIR) spectrum was recorded in the range from $400 \mathrm{~cm}^{-1}$ to $4000 \mathrm{~cm}^{-1}$. The ${ }^{1} \mathrm{H}$ and ${ }^{13} \mathrm{C}$ nuclear magnetic resonance (NMR) spectra were also recorded. DFT calculations were employed to support X-ray molecular geometry and calculate IR and NMR $\left({ }^{1} \mathrm{H}\right.$ and $\left.{ }^{13} \mathrm{C}\right)$ spectral bands. The structural (bond lengths, bond angles, torsion angles) and spectral (vibrational modes and chemical shifts) parameters obtained from DFT levels (B3LYP/6-31G(d,p) and B3LYP/6-31G+(d,p)) were compared with experimental findings, and an excellent harmony between the two data was ascertained.

Keywords: cyclobutane; thiazole; thiazolidine; SCXRD; IR; NMR

\section{ОПРЕДЕЛУВАњЕ НА СТРУКТУРАТА, АСИГНАЦИЈА НА ВИБРАЦИОНИ ЛЕНТИ И ХЕМИСКИ ПОМЕСТУВАЊА КАЈ 3-(4-(3-(2,5-ДИМЕТИЛФЕНИЛ)-3-МЕТИЛЦИКЛОБУТИЛ)ТИАЗОЛ-2-ИЛ)-2-(o- ТОЛИЛ)ТИАЗОЛИДИН-4-ОН: КОМБИНИРАНИ ЕКСПЕРИМЕНТАЛНИ И КВАНТНО ХЕМИСКИ СТУДИИ БАЗИРАНИ НА ТЕОРИЈАТА ЗА ГУСТИНА НА ФУНКЦИОНАЛОТ}

Во овој труд е изнесена анализата на насловното соединение по пат на рендгенска дифракција, Фуриеови трансформирани инфрацрвени (FTIR) спектри, нуклеарна магнетна резонанца (NMR) и пресметки со теорија на густина на функциноалот (DFT) во контекст на структурна карактеризација. Кристалните и молекулските структури на соединението беа детерминирани со рендгенска дифракција на монокристал (SCXRD). FTIR-спектарот беше снимен во областа од $400 \mathrm{~cm}^{-1}$ до $4000 \mathrm{~cm}^{-1}$. Беа снимени и ${ }^{1} \mathrm{H}$ и ${ }^{13} \mathrm{C}$ NMR-спектрите. Пресметките на DFT беа употребени за да ја потврдат молекулската структура добиена со рендгенската дифракција, како и да се пресметаат спектралните ленти на IR и NMR $\left({ }^{1} \mathrm{H}\right.$ и $\left.{ }^{13} \mathrm{C}\right)$. Структурните параметри (должина на врски, агли, торзиони агли) и спектралните параметри (вибрациони модови и хемиски поместувања) добиени од нивоата на DFT (B3LYP/6-31G(d,p) и B3LYP/6-31G+(d,p)) беа споредени со експерименталните вредности, при што беше утврдена хармонија меѓу едните и другите податоци.

Клучни зборови: циклобутан; тиазол; тиазолидин; SCXRD; IR; NMR 


\section{INTRODUCTION}

Chemistry and physics are branches of science that both study the structure and behavior of matter. Solid state chemistry, also known as material chemistry, is a common subdivision of these two sciences, which focus on the synthesis of new materials and their characterization. In recent years, due to the fact that most diseases are rapidly increasing worldwide, material scientists have aimed to synthesize new functional materials possessing promising biological and pharmaceutical characteristics, wherein these materials are expected to be used directly or indirectly in the treatment of diseases.

Cyclobutane, thiazole and thiazolidine derivatives, the synthesis of which is focused on here, and the structural and spectral characterization of new derivatives, have attracted attention in medicinal chemistry and biochemistry due to their wide range of various biological and pharmacological activities, including anti-microbial [1-6], anti-fungal [1, 7-9], anti-cancer [10-13] and anti-inflammatory [14-16] properties. These compounds, containing cyclobutane, thiazole and thiazolidine functions, appear to be suitable candidates for drug design. Furthermore, they have been used as ligand in coordination chemistry [17-20]. The current paper deals with the preparation, crystal structure and characterization of a novel compound which consists of these fragments.

Previously, as a part of our research program concerning the synthesis of new cyclobutane derivatives, we examined compounds containing different fragments [21-29]. This paper describes herein the synthesis, crystallographic features, spectral (FT-IR and NMR) characterization and DFT calculations of a new cyclobutane derivative with thiazole and thiazolidine, $\left[\mathrm{C}_{52} \mathrm{H}_{56} \mathrm{~N}_{4} \mathrm{O}_{2} \mathrm{~S}_{4}\right]$. This compound was synthesized in the same manner as depicted in the literature [25], with the use of appropriate starting substances and solvents. To the best of our knowledge, it is a novel compound that was first synthesized in our laboratories, so there is no report in the literature about this com- pound. In this paper, a combination of experimental and computational/theoretical methods has been used to determine the molecular structure (Xray and DFT) and spectral bands (FT-IR, NMR and DFT). The crystal and molecular geometry were revealed by a single crystal X-ray diffraction method. Following this, the initial geometry of the compound was obtained from the X-ray coordinates, and optimized by Density Functional Theory (DFT). The structure and spectra obtained from the geometry optimization were compared with the experimental data.

\section{EXPERIMENTAL AND THEORETICAL METHODS}

\subsection{Synthesis of compound}

The compound was synthesized in the same manner as depicted in the literature [25], with the use of appropriate starting substances and solvents. Overall yield: $47 \%$, melting point: $456 \mathrm{~K}(\mathrm{EtOH})$. White solid, yield: $47 \%$; m.p. $183{ }^{\circ} \mathrm{C}$ (EtOH). IR $\left(v / \mathrm{cm}^{-1}\right): \quad 2970-2870 \quad \mathrm{~cm}^{-1} \quad v($ aliphatics $), \quad 1697$ $v(\mathrm{C}=\mathrm{O}), 810 \mathrm{~cm}^{-1} v(\mathrm{C}-\mathrm{S}-\mathrm{C}$, thiazolidine $), 732 \mathrm{~cm}^{-1}$ $v(\mathrm{C}-\mathrm{S}-\mathrm{C}$, thiazole $) .{ }^{1} \mathrm{H}$ NMR shifts $\left(\mathrm{CDCl}_{3}, \delta\right.$, ppm): 1.48 (s, $3 \mathrm{H},-\mathrm{CH}_{3}$ on cyclobutane ring), 2.07 (s, $3 \mathrm{H},-\mathrm{CH}_{3}$ on phenyl ring), $2.17\left(\mathrm{~s}, 3 \mathrm{H}, o-\mathrm{CH}_{3}\right.$ on xylene ring), $2.38\left(\mathrm{~s}, 3 \mathrm{H}, m-\mathrm{CH}_{3}\right.$ on xylene ring), 2.22-2.29 (m, $2 \mathrm{H},-\mathrm{CH}_{2}-$ in cyclobutane ring), $2.39-2.45\left(\mathrm{~m}, 1 \mathrm{H},-\mathrm{CH}_{2 \mathrm{~A}^{-}}\right.$in cyclobutane ring), $2.59-2.64\left(\mathrm{t}, j=20 \mathrm{~Hz}, 1 \mathrm{H},-\mathrm{CH}_{2 \mathrm{~B}}\right.$ - in cyclobutane ring), $3.46-3.50$ (quint, $j=8.2 \mathrm{~Hz}, 1 \mathrm{H},>\mathrm{CH}$ on cyclobutane), $3.87\left(\mathrm{~d}, j=1.6 \mathrm{~Hz}, 1 \mathrm{H},-\mathrm{CH}_{2 \mathrm{~A}}-\mathrm{S}-\right)$, $4.08-4.13\left(\mathrm{dd}, j_{1}=1.3 \mathrm{~Hz}, j_{2}=16.4 \mathrm{~Hz}, 1 \mathrm{H},-\mathrm{CH}_{2 \mathrm{~B}}-\right.$ $\mathrm{S}-), 6.55(\mathrm{~s}, 1 \mathrm{H}, \mathrm{N}-\mathrm{CH}-\mathrm{S}), 6.74-6.77(\mathrm{~m}, 2 \mathrm{H}$, aromatics), $6.85-6.89(\mathrm{~d}, j=7.2 \mathrm{~Hz}, 1 \mathrm{H}$, aromatic), 6.95-7.00 (m, 2H, aromatics). ${ }^{13} \mathrm{C}$ NMR (100 MHz, DMSO, TMS): $\delta 170.18,155.61,154.89$, $149.37,138.94,135.03,134.97,131.43,130.98$, $130.60,127.75,126.51,126.48,126.37,123.44$, $107.32,60.31,41.75,41.32,39.49,32.90,30.88$, $27.78,21.17,19.55,18.56$.
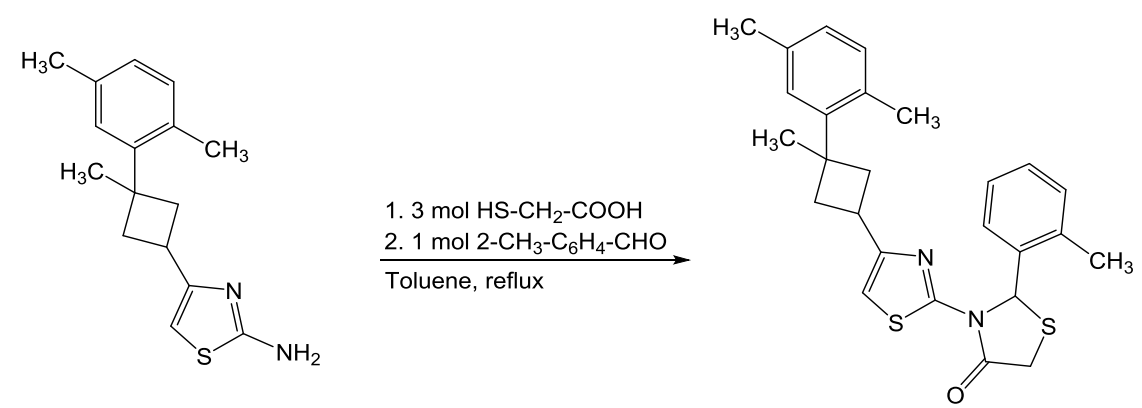

Scheme 1. Synthetic pathway for the synthesis of the target compound 


\section{2. $X$-ray diffraction analysis}

The X-ray diffraction data for the title compound was collected with a Bruker D8 QUEST diffractometer using graphite-monochromated Mo $\mathrm{K} \alpha$ at $296 \mathrm{~K}$. The crystal and molecular structures were solved by direct methods using SHELXS-97 [32] and refined by the full-matrix least-squares methods on $\mathrm{F}^{2}$ using SHELXL-97 [33] from within the WINGX suite of software [34]. All nonhydrogen atoms were refined with anisotropic parameters. After treating the $\mathrm{H}$ atoms using a riding model, they were positioned geometrically and the bond distances were fixed at $0.93,0.97$ and $0.96 \AA$ for $\mathrm{C}-\mathrm{H}, \mathrm{C}-\mathrm{H}_{2}$ and $\mathrm{C}-\mathrm{H}_{3}$ atoms, respectively. Supramolecular analyses were performed using the crystallographic tool PLATON [35]. Molecular structure diagrams were created using ORTEP-3 for publication. Details of the data collection conditions and the parameters of the refinement process are given in Table 1. Crystallographic data for the structure reported in this paper have been deposited in the Cambridge Crystallographic Data Center with CCDC number 1566022.

\section{Table 1}

Crystal data, data collection and structure refinement parameters for the title compound

\begin{tabular}{|c|c|}
\hline Crystal data & \\
\hline Chemical dormula & $\mathrm{C}_{52} \mathrm{H}_{56} \mathrm{~N}_{4} \mathrm{O}_{2} \mathrm{~S}_{4}$ \\
\hline Formula weight (a.k.b.) & 897.25 \\
\hline Temperature (K) & 296 \\
\hline Crystal system & Monoclinic \\
\hline Space group & $\mathrm{C} 2 / \mathrm{c}$ \\
\hline \multicolumn{2}{|l|}{ Unit cell parameters } \\
\hline $\mathrm{a} \neq \mathrm{b} \neq \mathrm{c}(\AA)$ & $24.322(5), 10.279(5), 20.801(5)$ \\
\hline$\alpha=\gamma \neq \beta\left(^{\circ}\right)$ & $90,116.034(5)$ \\
\hline Crystal size $(\mathrm{mm})$ & $0.15 \times 0.17 \times 0.21$ \\
\hline Volume, V $\left(\AA^{3}\right)$ & $4673(3)$ \\
\hline $\mathrm{Z}$ & 4 \\
\hline$\mu\left(\mathrm{mm}^{-1}\right)$ & 0.25 \\
\hline $\mathrm{F}_{000}$ & 1904 \\
\hline Calculated density $\left(\mathrm{Mg} / \mathrm{m}^{3}\right)$ & 1.275 \\
\hline \multicolumn{2}{|l|}{ Data collection } \\
\hline Diffractometer & Bruker D8 QUEST \\
\hline Wavelength (A) & $0.71073 \mathrm{Mo} \mathrm{K} \alpha$ \\
\hline$\theta$ range for data collection $\left(^{\circ}\right)$ & $3.2 \leq \theta \leq 28.9$ \\
\hline \multicolumn{2}{|l|}{ Index ranges: } \\
\hline $\mathrm{h}_{\min }, \mathrm{h}_{\max }$ & $-32,32$ \\
\hline $\mathrm{k}_{\min }, \mathrm{k}_{\max }$ & $-13,13$ \\
\hline $1_{\min }, 1_{\max }$ & $-27,27$ \\
\hline Reflections collected & 81848 \\
\hline Independent reflections & 5832 \\
\hline Observed reflections $[\mathrm{I}>2 \sigma(\mathrm{I})]$ & 4254 \\
\hline Absorption correction type & multi-scan \\
\hline \multicolumn{2}{|l|}{$\mathrm{T}_{\min }, \mathrm{T}_{\max }$} \\
\hline $\mathrm{R}_{\text {int }}$ & 0.060 \\
\hline \multicolumn{2}{|l|}{ Refinement } \\
\hline Least-squares matrix & Full \\
\hline$R\left[F^{2}>2 \sigma\left(F^{2}\right)\right]$ & 0.061 \\
\hline$w R\left(F^{2}\right)$ & 0.171 \\
\hline$G o o F=S$ & 1.05 \\
\hline Reflections/Parameters/Restraints & $5832 / 280 / 0$ \\
\hline Refinement method & SHELXL-97 \\
\hline$(\Delta / \sigma)_{\max }$ & 0.001 \\
\hline$\Delta \rho_{\min }, \Delta \rho_{\max }\left(\mathrm{e} / \AA^{3}\right)$ & $-0.84,0.77$ \\
\hline
\end{tabular}




\subsection{Spectral analysis}

The FT-IR spectrum of the title compound has been recorded as $\mathrm{KBr}$ pellets on a Mattson 1000 Fourier transform infrared spectrometer from the range of $4000-400 \mathrm{~cm}^{-1}$ in a solid phase at room temperature. The ${ }^{1} \mathrm{H}$ and ${ }^{13} \mathrm{C}$ nuclear magnetic resonance (NMR) spectra were recorded on a Varian-Mercury-Plus 400 $\mathrm{MHz}$ spectrometer using TMS as internal standard and $\mathrm{CDCl}_{3}$ (chloroform) as solvent.

\subsection{DFT calculation}

For modelling, X-ray coordinates were used as initial geometry, taken with the Babel operation on the Model tab in the WingGX software [34]. To obtain the electronic structure of compound, optimization calculations were performed at the DFT level by using the GAUSSIAN03 program package [36], wherein B3LYP function was chosen [30, 31], which combines Becke's three-parameter hybrid exchange function. To understand the effects of sets based on structural and spectral characteristics, 6-31G $(\mathrm{d}, \mathrm{p})$ [a polarized basis set] and $6-31 \mathrm{G}+(\mathrm{d}, \mathrm{p})$ [a diffuse basis set] were used in calculations. The structural parameters (bond distances, bond angles and torsion angles) and spectral assignments (vibration frequencies and chemical shifts) from the theoretical molecular structures [DFT/B3LYP/6$31 \mathrm{G}(\mathrm{d}, \mathrm{p})$ and DFT/B3LYP/6-31G+(d,p)] were compared with their experimental (X-ray diffraction, FT-IR and NMR) data.

\section{RESULTS AND DISCUSSION}

\subsection{Structural description of the title compound}

The title compound, 3-(4-(3-(2,5-dimethylphenyl)-3-methylcyclobutyl)thiazol-2-yl)-2-(otolyl) thiazolidin-4-one, is shown in Figure 1 in the Ortep-3 [37] view. Single crystal X-ray diffraction results show that the crystal structure of the compound crystallizes in space group $\mathrm{C} 2 / \mathrm{c}$ and it belongs to the monoclinic system with the following cell dimensions: $a=24.322$ (5) $\AA, b=10.279$ (5) $\AA$, $c=20.801$ (5) $\AA, \beta=116.034$ (5), $Z=4$.

The compound is composed of a central thiazole ring, with an 2-(o-tolyl)thiazolidine group connected to the 2-position of the ring and a 1,4dimethyl-2-(1-methylcyclobutyl)benzene group in the 4-position. The cyclobutane and thiazolidine rings are cis-related to thiazole ring. The cyclobutane adopted a butterfly conformation. The bond distance between the carbon atoms are $1.556 \AA$ on average and bond angles formed by the three carbons are $88.66^{\circ}$ on average. When these values are compared with the previously reported cyclobutane derivatives [21-29, 38-41], it can be seen that there are no considerable differences.

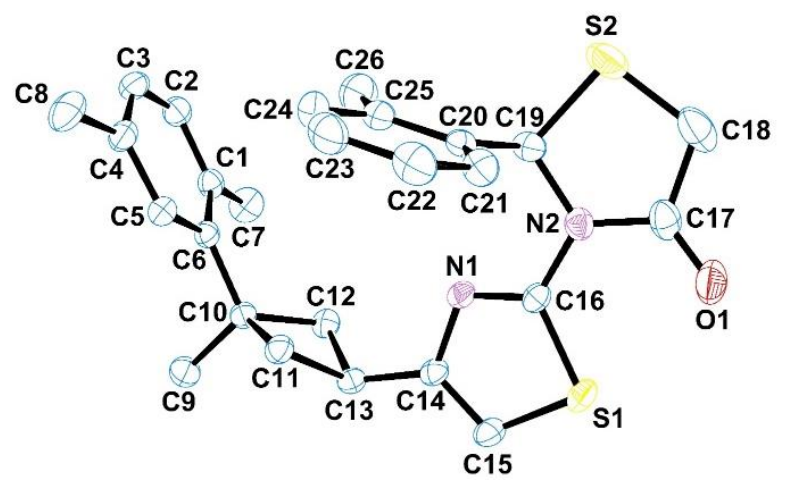

Fig. 1. ORTEP-3 representation of the molecular structures of the title compound

The dihedral angles between cyclobutane planes are $24.93(28)^{\circ} \quad(\mathrm{C} 10 / \mathrm{C} 11 / \mathrm{C} 13-$ $\mathrm{C} 13 / \mathrm{C} 12 / \mathrm{C} 10)$ and $24.52(25)^{\circ}(\mathrm{C} 11 / \mathrm{C} 10 / \mathrm{C} 12-$ $\mathrm{C} 12 / \mathrm{C} 13 / \mathrm{C} 11)$. Although close to being planar, the thiazole ring possesses a maximum deviation of $0.0034(14) \AA$. The S1-C15 and S1-C16 bond lengths are 1.723 (3) $\AA$ and 1.727 (2) $\AA$, respectively. These values are shorter than the accepted value for an $\mathrm{S}$ $\mathrm{C}_{\mathrm{sp}}{ }^{2}$ single bond (1.76 A) [42]. The $\mathrm{C}=\mathrm{N}$ bond length [1.298 (3) $\AA]$ for thiazole is approximately the same as those in previous publications; 1.2998 (17) [43], 1.300 (2) [44] and 1.299 (6) [25]. Thiazolidin-4-one is a thiazolidine derivative, and has a double-bonded oxygen connected to the 4-position of the thiazolidine ring. $\mathrm{N}-\mathrm{C}(\mathrm{N} 2-\mathrm{C} 17$ and $\mathrm{N} 2-\mathrm{C} 19), \mathrm{S}-\mathrm{C}(\mathrm{S} 2-\mathrm{C} 18$ and S1-C19), and $\mathrm{C}=\mathrm{O}(\mathrm{C} 17=\mathrm{O} 1)$ were found to be $1.419 \AA, 1.811 \AA$ and $1.214 \AA$, respectively, on average. The dihedral angles between the cyclobutane plane A (C11-C14), the thiazole plane B $(\mathrm{C} 14 / \mathrm{C} 15 / \mathrm{S} 1 / \mathrm{C} 16 / \mathrm{N} 1)$ and the thiazolidin-4-one plane $\mathrm{C}(\mathrm{C} 17 / \mathrm{C} 18 / \mathrm{S} 2 / \mathrm{C} 19 / \mathrm{N} 2 / \mathrm{O} 1)$ are $86.71(11)^{\circ}$ $(\mathrm{A} / \mathrm{B}), 10.91(13)^{\circ}(\mathrm{B} / \mathrm{C})$ and $83.01(11)^{\circ}$.

Analysis of the crystal structure of compound with PLATON [35] revealed that there are six intramolecular and three inter-molecular interactions, the details of which are given in Table 2. Intramolecular interactions consist of four $\mathrm{C}-\mathrm{H} \cdots \mathrm{N}$ (Fig. 2a) and two $\mathrm{C}-\mathrm{H} \cdots \mathrm{Cg}$ ( $\pi$-ring) (edge-to-face) (Fig $2 \mathrm{~b}$ ). The thiazole N1 atom and thiazolidin-4-one N2 atom act as hydrogen-acceptor with average $\mathrm{H} \cdots \mathrm{A}$ distances of $2.7 \AA$. C26 and $\mathrm{C} 21$ atoms forms a C$\mathrm{H} \cdots \mathrm{Cg}(\pi$-ring) contact via atoms $\mathrm{H} 26$ and $\mathrm{H} 21$ with the centroid of the $(\mathrm{C} 1-\mathrm{C} 6)$ and thiazolidin-4-one rings, respectively. All of these intra-molecular interactions contribute to the formation of the cis position of the compound. Inter-molecular interactions consist of two $\mathrm{C}-\mathrm{H} \cdots \mathrm{O}$ and two $\mathrm{C}-\mathrm{H} \cdots \mathrm{Cg}(\pi$-ring $)$ (edge-to-face). 
Table 2

Hydrogen-bond geometry $\left(\AA,{ }^{\circ}\right)$

\begin{tabular}{lcccc}
\hline \hline $\mathbf{D}-\mathbf{H} \cdots \mathbf{A}$ & $\mathbf{D}-\mathbf{H}$ & $\mathbf{H} \cdots \mathbf{A}$ & $\mathbf{D} \cdots \mathbf{A}$ & $\mathbf{D}-\mathbf{H} \cdots \mathbf{A}$ \\
\hline $\mathrm{C} 21-\mathrm{H} 21 \cdots \mathrm{N} 2$ & 0.93 & 2.68 & $2.941(3)$ & 97 \\
$\mathrm{C} 19-\mathrm{H} 19 \cdots \mathrm{N} 1$ & 0.98 & 2.61 & $2.744(3)$ & 87 \\
$\mathrm{C} 12-\mathrm{H} 12 A \cdots \mathrm{N} 1$ & 0.97 & 2.73 & $3.076(3)$ & 101 \\
$\mathrm{C} 11-\mathrm{H} 11 A \cdots \mathrm{N} 1$ & 0.97 & 2.79 & $3.115(3)$ & 100 \\
$\mathrm{C} 23-\mathrm{H} 23 \cdots \mathrm{O} 1^{\mathrm{a}}$ & 0.93 & 2.64 & $3.522(4)$ & 159 \\
$\mathrm{C} 18-\mathrm{H} 18 B \cdots \mathrm{O} 1^{\mathrm{b}}$ & 0.97 & 2.77 & $3.696(4)$ & 160 \\
\hline $\mathbf{D}-\mathbf{H} \cdots \mathbf{C g}$ & $\mathbf{D}-\mathbf{H}$ & $\mathbf{H} \cdots \mathbf{C g}$ & $\mathbf{D} \cdots \mathbf{C g}$ & $\mathbf{D}-\mathbf{H} \cdots \mathbf{C g}$ \\
\hline $\mathrm{C} 21-\mathrm{H} 21 \cdots \mathrm{Cg} 1$ & 0.93 & 2.73 & $3.046(4)$ & 101 \\
$\mathrm{C} 26-\mathrm{H} 26 B \cdots \mathrm{Cg} 2$ & 0.96 & 2.87 & $3.569(4)$ & 130 \\
$\mathrm{C} 12-\mathrm{H} 12 B \cdots \mathrm{Cg} 2^{\mathrm{c}}$ & 0.97 & 2.82 & $3.781(3)$ & 169 \\
\hline \hline
\end{tabular}

Symmetry codes: (a) $\mathrm{x}, \mathrm{y}+1, \mathrm{z}$; (b) $-\mathrm{x}+1, \mathrm{y},-\mathrm{z}+3 / 2$; (c) $1 / 2-\mathrm{x},-1 / 2+\mathrm{y}, 1 / 2-\mathrm{z}$.

$\mathrm{Cg} 1$ is the centroid of the thiazolidin $(\mathrm{N} 2, \mathrm{C} 17, \mathrm{C} 18, \mathrm{~S} 2, \mathrm{C} 19)$ ring.

$\mathrm{Cg} 2$ is the centroid of the phenyl $(\mathrm{C} 1, \mathrm{C} 2, \mathrm{C} 3, \mathrm{C} 4, \mathrm{C} 5, \mathrm{C} 6)$ ring.

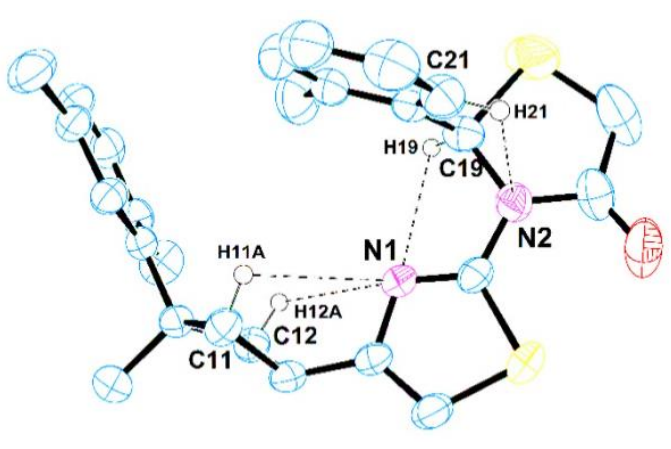

(a)



(b)

Fig. 2. a) Intra-molecular $\mathrm{D}-\mathrm{H} \cdots \mathrm{A}$ type hydrogen bonds $(\mathrm{C} 21-\mathrm{H} 21 \cdots \mathrm{N} 2, \mathrm{C} 19-\mathrm{H} 19 \cdots \mathrm{N} 1, \mathrm{C} 12-\mathrm{H} 12 A \cdots \mathrm{N} 1$ and $\mathrm{C} 11-\mathrm{H} 11 A \cdots \mathrm{N} 1)$, b) Intra-molecular $\mathrm{D}-\mathrm{H} \cdots \pi$ type hydrogen bonds $(\mathrm{C} 21-\mathrm{H} 21 \cdots \mathrm{Cg} 1$ and $\mathrm{C} 26-\mathrm{H} 26 B \cdots \mathrm{Cg} 2)$

Thiazolidin-4-one atom $\mathrm{O} 1$ in the molecule at $(-\mathrm{x}+1, \mathrm{y},-\mathrm{z}+3 / 2)$ acts as hydrogen-acceptor, via atom $\mathrm{H} 18 \mathrm{~B}$, to thiazolidin-4-one atom $\mathrm{C} 18$ in the molecule at $(\mathrm{x}, \mathrm{y}, \mathrm{z})$, which this interaction forms an $R_{2}^{2}(8)$ motif (Fig. 3).

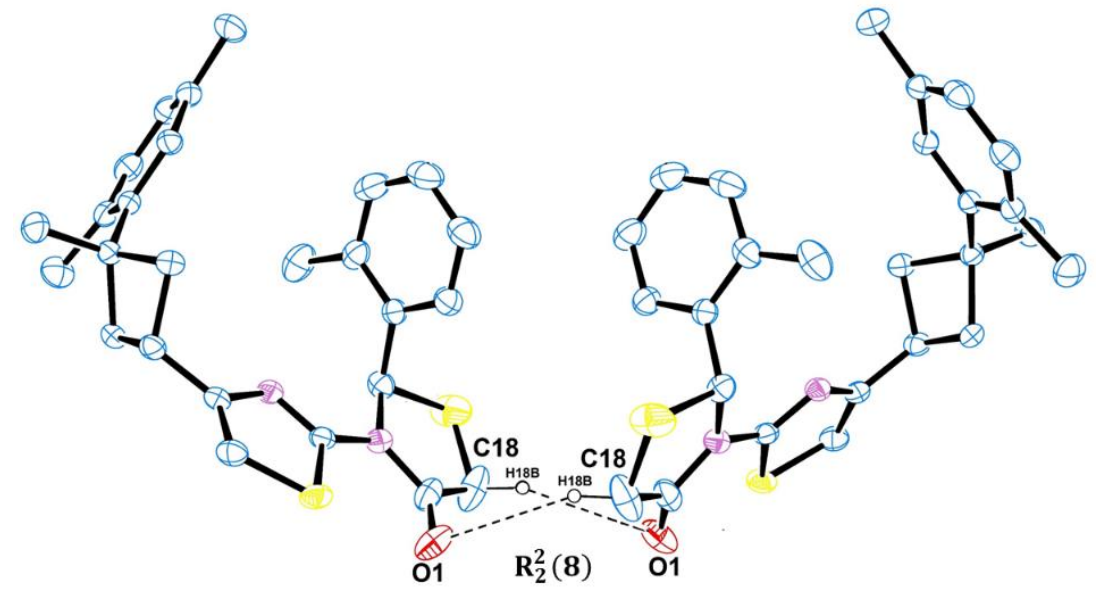

Fig. 3. Part of the crystal structure of the title compound, showing the formed $\boldsymbol{R}_{\mathbf{2}}^{2}(\mathbf{8})$ motif. For clarity, only $\mathrm{H}$ atoms involved in hydrogen bonding have been included 
The same thiazolidin-4-one atom $\mathrm{O} 1$ in the molecule at $(\mathrm{x}, \mathrm{y}+1, \mathrm{z})$ acts as hydrogen-acceptor donor, via atom $\mathrm{H} 23$, to atom $\mathrm{C} 23$ in the molecule at $(\mathrm{x}, \mathrm{y}, \mathrm{z})$. Atom $\mathrm{C} 12$ at $(\mathrm{x}, \mathrm{y}, \mathrm{z})$ forms a $\mathrm{C}$ $\mathrm{H} \cdots \mathrm{Cg}(\pi$-ring $)$ contact, via atom $\mathrm{H} 12 \mathrm{~B}$, with the centroid of the $\mathrm{C} 1-\mathrm{C} 6$ ring [fractional centroid coordinates: $0.15137(4), 0.48700(10), 0.16341(5)]$ of the molecule at $(1 / 2-\mathrm{x},-1 / 2+\mathrm{y}, 1 / 2-\mathrm{z})$.

\subsection{DFT molecular modeling studies}

\subsubsection{Theoretical (DFT/B3LYP) molecular structures}

Density functional theory (DFT) calculations of the molecular geometries, electronic structure parameters and spectral assignments have been carried out using the B3LYP/6-31G $(d, p)$ and B3LYP/6-31G+(d,p) levels. These DFT molecular structures of with the atom numbering scheme are shown in Figure 4, wherein B3LYP/6-31G(d,p) method is shown in red and the B3LYP/6$31 \mathrm{G}+(\mathrm{d}, \mathrm{p})$ method is shown in blue. This marking was also used in the spectral analysis.

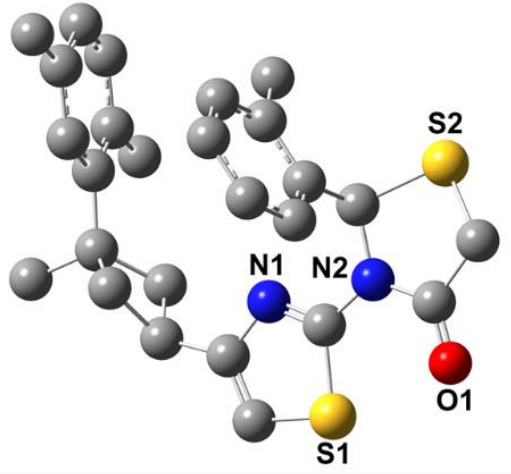

6-31G(d, p)

a)

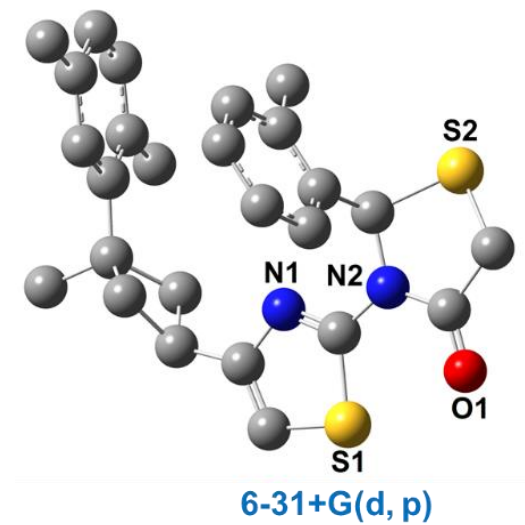

b)

Fig. 4. DFT optimized structures [a) DFT/B3LYP/6-31G(d,p) and b) DFT/B3LYP/6-31G+(d,p)]

Table 3

Total-zero-point energy, entropy, heat capacity, rotational constants, and dipole moments for the optimized structure

\begin{tabular}{lcc}
\hline \multirow{2}{*}{ Parameters } & \multicolumn{2}{c}{ DFT/B3LYP } \\
\cline { 2 - 3 } & $\mathbf{6 - 3 1 G ( d , p )}$ & $\mathbf{6 - 3 1 G + ( d , p )}$ \\
\hline Total energy (a.u.) & -1988.78398649 & -1988.82018595 \\
Zero-point vibrational energy (kcal/mol) & 303.53436 & 302.64443 \\
Entropy (cal/mol-K) & 195.545 & 198.487 \\
Heat capacity at const. volume (CV, cal/mol-K) & 113.602 & 113.915 \\
\hline Rotational constants (GHz) & & \\
\hline A & 0.18256 & 0.17997 \\
B & 0.09969 & 0.09481 \\
C & 0.07934 & 0.07598 \\
\hline Dipole moment (Debye) & & 1.7491 \\
\hline$\mu_{x}$ & -1.7033 & 1.0279 \\
$\mu_{y}$ & -0.8336 & -0.6211 \\
$\mu_{z}$ & -0.6844 & 2.1217 \\
$\mu_{\text {top. }}$ & 2.0161 & \\
\hline \hline
\end{tabular}

\subsubsection{Structural comparison}

The DFT optimized calculations were actualized to support the X-ray molecular structure. The initial molecular geometry was as obtained from the single crystal X-ray diffraction, which was optimized using the density functional theory (DFT/B3LYP) method with the 6-31G(d,p) and 6$31 \mathrm{G}+(\mathrm{d}, \mathrm{p})$ basis sets. Some selected structural parameters revealed from X-ray diffraction and calculated by DFT/B3LYP levels are listed in Table 4. 
Table 4

Some selected geometric parameters

(bond lengths, bond angles and torsion angles) for the title compound $\left(A,{ }^{\circ}\right)$

\begin{tabular}{|c|c|c|c|c|}
\hline \multirow{2}{*}{$\begin{array}{l}\text { Geometric } \\
\text { parameters }\end{array}$} & \multirow{2}{*}{\multicolumn{2}{|c|}{$\begin{array}{c}\text { Experimental } \\
{[\mathrm{X}-\mathrm{ray}]}\end{array}$}} & \multicolumn{2}{|c|}{ DFT/B3LYP } \\
\hline & & & 6-31G(d,p) & $6-31 G+(d, p)$ \\
\hline \multicolumn{5}{|l|}{ Bond lengths $(\AA)$} \\
\hline $\mathrm{C} 1-\mathrm{C} 2$ & $1.394(4)$ & & 1.399 & 1.401 \\
\hline $\mathrm{C} 2-\mathrm{C} 3$ & $1.382(4)$ & & 1.394 & 1.395 \\
\hline $\mathrm{C} 6-\mathrm{C} 10$ & $1.518(3)$ & & 1.525 & 1.525 \\
\hline $\mathrm{C} 9-\mathrm{C} 10$ & $1.530(3)$ & & 1.541 & 1.542 \\
\hline $\mathrm{C} 10-\mathrm{C} 11$ & $1.561(3)$ & & 1.564 & 1.565 \\
\hline $\mathrm{C} 13-\mathrm{C} 14$ & $1.492(3)$ & & 1.496 & 1.496 \\
\hline $\mathrm{C} 14-\mathrm{N} 1$ & $1.390(3)$ & & 1.383 & 1.383 \\
\hline $\mathrm{C} 14-\mathrm{C} 15$ & $1.350(3)$ & & 1.364 & 1.367 \\
\hline $\mathrm{C} 15-\mathrm{S} 1$ & $1.723(3)$ & & 1.744 & 1.742 \\
\hline $\mathrm{C} 16-\mathrm{N} 2$ & $1.404(3)$ & & 1.394 & 1.396 \\
\hline $\mathrm{N} 2-\mathrm{C} 17$ & $1.368(3)$ & & 1.382 & 1.382 \\
\hline $\mathrm{C} 17-\mathrm{O} 1$ & $1.214(4)$ & & 1.219 & 1.221 \\
\hline $\mathrm{C} 18-\mathrm{S} 2$ & $1.785(4)$ & & 1.826 & 1.826 \\
\hline \multirow[t]{2}{*}{$\mathrm{C} 19-\mathrm{C} 20$} & $1.512(3)$ & & 1.517 & 1.517 \\
\hline & & $\mathrm{R}^{2}$ & 0.9963 & 0.9961 \\
\hline \multicolumn{5}{|l|}{ Bond angles $\left({ }^{\circ}\right)$} \\
\hline $\mathrm{C} 1-\mathrm{C} 2-\mathrm{C} 3$ & $122.7(2)$ & & 122.17 & 122.19 \\
\hline $\mathrm{C} 6-\mathrm{C} 10-\mathrm{C} 9$ & $109.44(19)$ & & 110.09 & 109.84 \\
\hline $\mathrm{C} 10-\mathrm{C} 11-\mathrm{C} 13$ & $89.50(17)$ & & 89.84 & 89.64 \\
\hline $\mathrm{C} 13-\mathrm{C} 14-\mathrm{N} 1$ & $118.40(19)$ & & 118.52 & 119.39 \\
\hline $\mathrm{C} 15-\mathrm{S} 1-\mathrm{C} 16$ & $87.73(11)$ & & 87.42 & 87.51 \\
\hline $\mathrm{N} 1-\mathrm{C} 16-\mathrm{N} 2$ & $120.3(2)$ & & 121.18 & 121.36 \\
\hline $\mathrm{N} 2-\mathrm{C} 17-\mathrm{O} 1$ & $123.5(3)$ & & 123.97 & 123.89 \\
\hline $\mathrm{C} 17-\mathrm{N} 2-\mathrm{C} 19$ & $119.4(2)$ & & 118.45 & 117.90 \\
\hline \multirow[t]{2}{*}{$\mathrm{S} 2-\mathrm{C} 19-\mathrm{C} 20$} & $111.10(16)$ & & 113.37 & 113.25 \\
\hline & & $\mathrm{R}^{2}$ & 0.9954 & 0.9943 \\
\hline \multicolumn{5}{|l|}{ Torsion angles $\left({ }^{\circ}\right)$} \\
\hline $\mathrm{C} 5-\mathrm{C} 6-\mathrm{C} 10-$ & $89.2(2)$ & & 96.03 & 95.33 \\
\hline $\mathrm{C} 6-\mathrm{C} 10-\mathrm{C} 12-$ & $135.64(19)$ & & 136.07 & 137.26 \\
\hline $\mathrm{C} 12-\mathrm{C} 13-$ & $47.1(3)$ & & 51.87 & 52.35 \\
\hline $\mathrm{C} 18-\mathrm{C} 17-\mathrm{N} 2-$ & $171.9(2)$ & & 178.22 & 177.75 \\
\hline \multirow[t]{2}{*}{$\mathrm{C} 20-\mathrm{C} 19-\mathrm{N} 2-$} & $64.5(3)$ & & 76.43 & 77.89 \\
\hline & & $\mathrm{R}^{2}$ & 0.9942 & 0.9941 \\
\hline
\end{tabular}

There are two conventional methods used in structural comparison. The first method is to calculate the correlation value $\left(\mathrm{R}^{2}\right)$ which shows the correlation between experimental and theoretical parameters. The calculated $\mathrm{R}^{2}$ values are $0.9963(y$ $=1.0503 x-0.0652)$ and $0.9961(y=1.0448 x-$ $0.0563)$ for bond lengths, $0.9954(y=0.9993 x+$ $0.4093)$ and $0.9943(y=1.0028 x+0.0123)$ for bond angles, $0.9942(y=0.9688 x+9.2245)$ and $0.9941(y=0.9628 x+10.233)$ for torsion angles at 6-31G(d,p) and 6-31G+(d,p) levels, respectively. The second method is to calculate the Root Mean Square Error (RMSE) which obtained by superimposing the molecular skeletons (X-ray and DFT skeletons). They show the superimposed view of $\mathrm{X}$-ray and DFT/B3LYP structures in Figure 5 giving a RMSE of $0.336 \AA$ and $0.459 \AA$ for 6$31 \mathrm{G}(\mathrm{d}, \mathrm{p})$ and $6-31+\mathrm{G}(\mathrm{d}, \mathrm{p})$ levels. According to these results (both $\mathrm{R}^{2}$ and RMSE), it may be concluded that the $6-31 \mathrm{G}(\mathrm{d}, \mathrm{p})$ calculation reproduces the geometry of the title compound well.

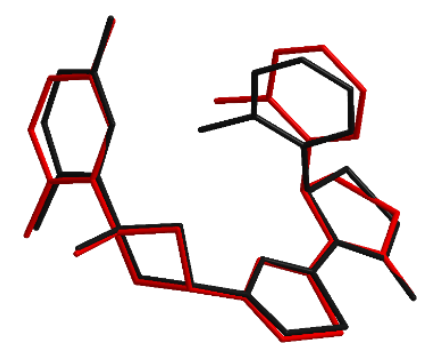

a)

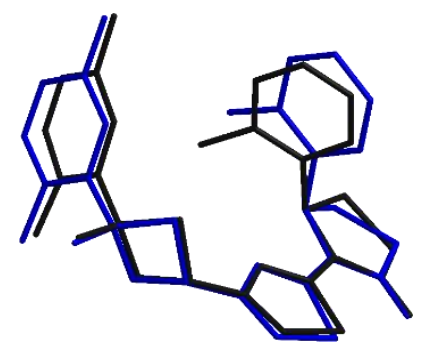

b)

Fig. 5. Atom-by-atom superimposition of the structures calculated [a) DFT/B3LYP/6-31G(d,p) (red),

b) DFT/B3LYP/6-31G+(d,p) (blue)] over the X-ray structure (black) for the title compound 


\subsection{Spectroscopic characterization}

\subsubsection{IR spectra}

The IR spectra and vibrational bands were investigated in detail; experimental results were supported by the theoretical IR calculation, where vibrational spectrum and vibrational frequencies were calculated using the density functional theory (DFT/B3LYP) method by means of optimized geometries. To provide harmony between the theoretical/calculated and experimental frequencies, the scaling factor was applied to all of the calculated frequencies. Scaling factors are given as 0.9608 for B3LYP/6-31G(d,p) and 0.9648 for B3LYP/6-
$31 \mathrm{G}+(\mathrm{d}, \mathrm{p})[45,46]$ levels. Figure 6 illustrates the superimposed experimental and scaled theoretical IR spectra of the title compound in the frequency range from 4000 to $400 \mathrm{~cm}^{-1}$.

The title compound belongs to $\mathrm{C} 1$ point group symmetry since it does not have a special symmetry. The normal mode number for $\mathrm{C} 1 \mathrm{sym}-$ metry can be easily calculated using the formula $3 \mathrm{~N}-6$, where $\mathrm{N}$ is the number of atoms. The compound consists of 59 atoms; hence it has 171 vibrational modes. Some vibrational modes were assigned by Gauss View software [47], and are shown in Table 5 with their corresponding FT-IR frequencies.

Table 5

Comparison of the observed and calculated (scaled) vibrational assignments of the title compound

\begin{tabular}{|c|c|c|c|}
\hline \multirow{2}{*}{ Assignments } & \multirow{2}{*}{$\begin{array}{l}\text { Experimental IR } \\
\text { with } \mathrm{KBr}\left(\mathrm{cm}^{-1}\right)\end{array}$} & \multicolumn{2}{|c|}{ Calculated [DFT/B3LYP] $\left(\mathrm{cm}^{-1}\right)$} \\
\hline & & 6-31G(d,p) & 6-31G+(d,p) \\
\hline$v \mathrm{C}-\mathrm{H}_{\text {thiazole }}$ & 3105 & 3136 & 3145 \\
\hline$v_{\mathrm{s}} \mathrm{C}-\mathrm{H}_{\text {aromatic }}$ & - & 3083 & 3095 \\
\hline$v_{\text {as }} \mathrm{C}-\mathrm{H}_{\text {aromatic }}$ & 3048 & 3071 & 3085 \\
\hline$v_{\text {as }} \mathrm{C}-\mathrm{H}_{\text {aromatic }}$ & 3048 & 3061 & 3074 \\
\hline$v_{\mathrm{s}} \mathrm{C}-\mathrm{H}_{\text {aromatic }}$ & - & 3059 & 3070 \\
\hline$v_{\text {as }} \mathrm{C}-\mathrm{H}_{\text {aromatic }}$ & 3048 & 3052 & 3063 \\
\hline$v_{\text {as }} \mathrm{C}-\mathrm{H}_{\text {aromatic }}$ & 3048 & 3040 & 3052 \\
\hline$v_{\text {as }} \mathrm{C}-\mathrm{H}_{2 \text { thiazolidine }}$ & - & 3029 & 3039 \\
\hline$v_{\text {as }} \mathrm{C}-\mathrm{H}_{2 \text { cyclobutane }}$ & 3019 & 3013 & 3019 \\
\hline$v \mathrm{C}-\mathrm{H}_{\text {cyclobutane }}$ & - & 2962 & 2969 \\
\hline$v_{\mathrm{s}} \mathrm{C}-\mathrm{H}_{2 \text { thiazolidine }}$ & - & 2954 & 2962 \\
\hline$v_{\mathrm{s}} \mathrm{C}-\mathrm{H}_{2 \text { cyclobutane }}$ & 2964 & 2940 & 2955 \\
\hline$v_{\mathrm{s}} \mathrm{C}-\mathrm{H}_{2 \text { cyclobutane }}$ & 2964 & 2943 & 2948 \\
\hline$v_{\mathrm{s}} \mathrm{C}-\mathrm{H}_{3}$ & 2924 & 2929 & 2937 \\
\hline$v_{\mathrm{s}} \mathrm{C}-\mathrm{H}_{3}$ & 2924 & 2919 & 2927 \\
\hline$v_{\mathrm{s}} \mathrm{C}-\mathrm{H}_{3 \text { cyclobutane }}$ & 2862 & 2918 & 2925 \\
\hline$v_{\mathrm{s}} \mathrm{C}-\mathrm{H}_{3}$ & 2924 & 2916 & 2924 \\
\hline$v \mathrm{C}=\mathrm{O}$ & 1694 & 1715 & 1696 \\
\hline$v \mathrm{C}=\mathrm{C}_{\text {thiazole }}$ & 1607 & 1523 & 1527 \\
\hline$\nu \mathrm{C}=\mathrm{N}_{\text {thiazole }}$ & 1530 & 1491 & 1482 \\
\hline$\alpha \mathrm{C}-\mathrm{H}_{2 \text { cyclobutane }}$ & 1490 & 1425 & 1426 \\
\hline$\alpha \mathrm{C}-\mathrm{H}_{2 \text { thiazolidine }}$ & - & 1418 & 1413 \\
\hline$v_{\mathrm{s}} \mathrm{C}-\mathrm{H}_{3 \text { cyclobutane }}$ & 1378 & 1366 & 1365 \\
\hline$\gamma \mathrm{C}-\mathrm{H}_{\text {thiazole }}$ & - & 1326 & 1331 \\
\hline$v \mathrm{C}-\mathrm{N}_{\text {thiazole }}$ & 1283 & 1296 & 1297 \\
\hline$\omega \mathrm{C}-\mathrm{H}_{2 \text { thiazolidine }}$ & - & 1205 & 1211 \\
\hline$\omega \mathrm{C}-\mathrm{H}_{2 \text { cyclobutane }}$ & 1220 & 1201 & 1201 \\
\hline$\delta \mathrm{C}-\mathrm{H}_{2 \text { thiazolidine }}$ & - & 1104 & 1110 \\
\hline$\delta \mathrm{C}-\mathrm{H}_{2 \text { cyclobutane }}$ & 1022 & 1032 & 1030 \\
\hline$\theta_{\text {cyclobutane }}$ & 905 & 929 & 931 \\
\hline$v \mathrm{C}-\mathrm{S}-\mathrm{C}_{\text {thiazolidine }}$ & - & 775 & 778 \\
\hline$v \mathrm{C}-\mathrm{S}-\mathrm{C}_{\text {thiazole }}$ & 732 & 748 & 759 \\
\hline
\end{tabular}

Vibrational modes: $\nu$, stretching; $\alpha$, scissoring; $\gamma$, rocking; $\omega$, wagging; $\delta$, twisting; $\theta$, ring breathing.

Abbreviations: s, symmetric; as, asymmetric. 


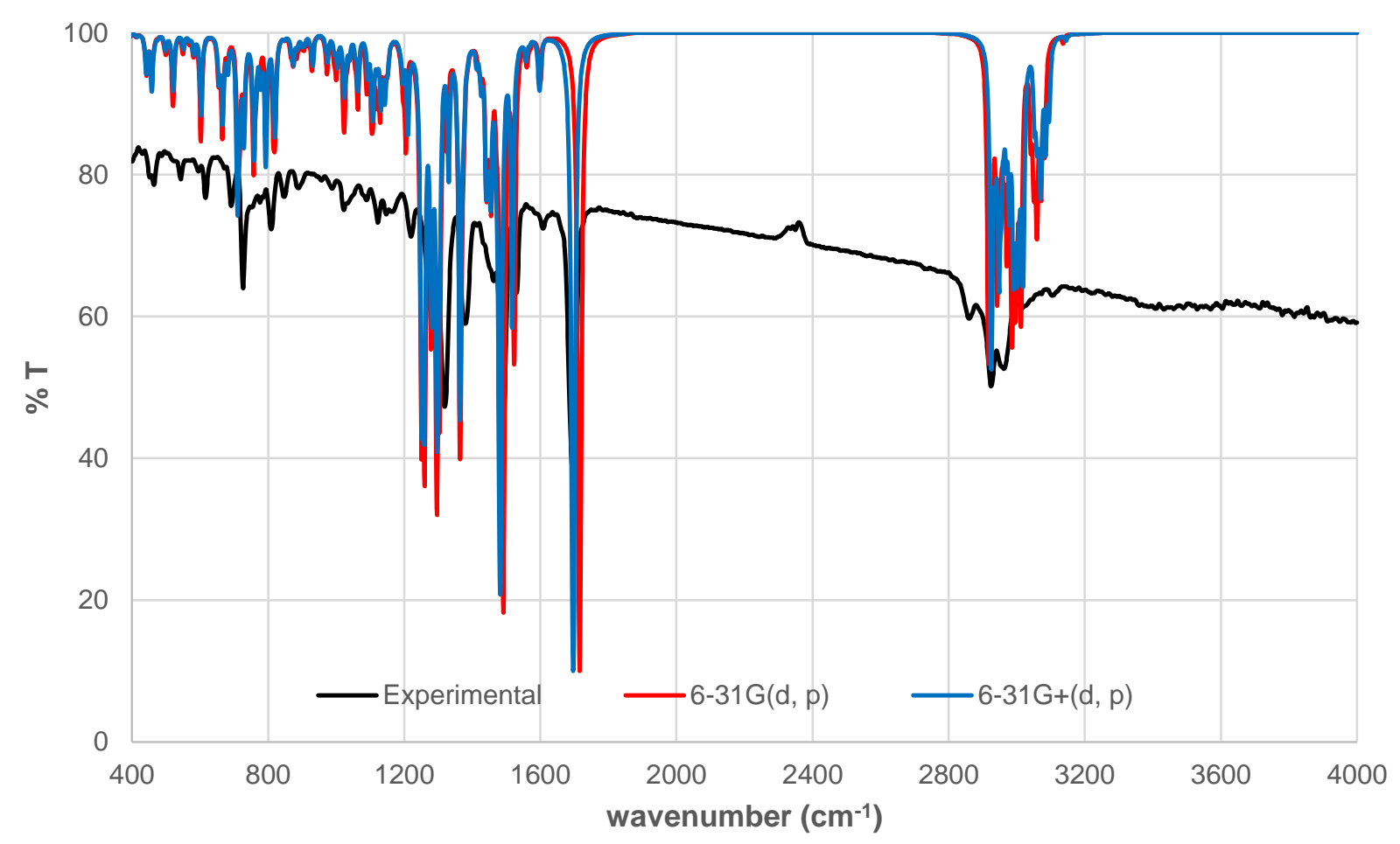

Fig. 6. Experimental (FT-IR) (black), DFT/B3LYP/6-31G(d,p) (red) and DFT/B3LYP/6-31G+(d,p) (blue) of vibration spectra of the title compound

To enable comparison with experimental observations, it was calculated the correlation coefficients for B3LYP/6-31G(d,p) and B3LYP/6$31 \mathrm{G}+(\mathrm{d}, \mathrm{p})$ levels, which is 0.9988 for vibrational modes, respectively. According to correlation value, both methods have given good results and there is no superiority to each other. The remarkable vibrations to be obtained from the IR study are the following:

\subsubsection{Cyclobutane vibrations}

For cyclobutane fragments, it is well-known that asymmetric and symmetric $\mathrm{C}-\mathrm{H}_{2}$ stretching, $\mathrm{C}-\mathrm{H}_{3}$ stretching, $\mathrm{C}-\mathrm{H}_{2}$ scissoring, $\mathrm{C}-\mathrm{H}_{2}$ wagging, $\mathrm{C}-\mathrm{H}_{2}$ twisting, ring breathing observed and calculated in region of 3100-2900, 2900-2800 and 1400-1300, 1500-1400, 1200-1100, 1100-1000, and $1000-900 \mathrm{~cm}^{-1}$, respectively [23-29]. The vibrational frequencies $\left(\mathrm{cm}^{-1}\right)$ obtained from the IR spectrum of the compound are given below:

i. anti-symmetric $\mathrm{C}-\mathrm{H}_{2}$ stretching: 3019 (Exp.) and 3013,3019 (Cal.)

ii. symmetric $\mathrm{C}-\mathrm{H}_{2}$ stretching: 2964 (Exp.), 2948, 2943 (6-31G(d,p)), 2955, 2948 (6$31 \mathrm{G}+(\mathrm{d}, \mathrm{p}))$

iii. $\mathrm{C}-\mathrm{H}_{3}$ stretching: 2862 and 1378 (Exp.), 2918 and 1366 (6-31G(d,p)), 2925 and 1368 $(6-31 \mathrm{G}+(\mathrm{d}, \mathrm{p}))$ iv. $\mathrm{C}-\mathrm{H}_{2}$ scissoring: 1490 (Exp.), 1425 (6$31 \mathrm{G}(\mathrm{d}, \mathrm{p})), 1426(6-31 \mathrm{G}+(\mathrm{d}, \mathrm{p}))$

v. $\mathrm{C}-\mathrm{H}_{2}$ wagging: 1220 (Exp.), 1201 (6$31 \mathrm{G}(\mathrm{d}, \mathrm{p})), 1201(6-31 \mathrm{G}+(\mathrm{d}, \mathrm{p}))$

vi. $\mathrm{C}-\mathrm{H}_{2}$ twisting: 1022 (Exp.), 1032 (6$31 \mathrm{G}(\mathrm{d}, \mathrm{p})), 1030(6-31 \mathrm{G}+(\mathrm{d}, \mathrm{p}))$

vii. ring breathing: 905 (Exp.), 929 (6$31 \mathrm{G}(\mathrm{d}, \mathrm{p})), 931(6-31 \mathrm{G}+(\mathrm{d}, \mathrm{p}))$

It can be seen that these vibration frequencies are consistent with previous publications on cyclobutane derivatives [23-29].

\subsubsection{Thiazole vibrations}

It was recorded five bands $\left(\mathrm{cm}^{-1}\right)$ belonging to the thiazole in the IR spectra. These bands are:

i. C-H stretching: 3105 (Exp.), 3136 and 3145 (Cal.)

ii. $\mathrm{C}=\mathrm{C}$ stretching: 1607 (Exp.), 1523 and 1517 (Cal.)

iii. $\mathrm{C}=\mathrm{N}$ stretching: 1530 (Exp.), 1491 and 1482 (Cal.)

iv. $\mathrm{C}-\mathrm{N}$ stretching: 1283 (Exp.), 1296 and 1297 (Cal.)

v. $\mathrm{C}-\mathrm{S}-\mathrm{C}$ stretching: 732 (Exp.), 748 and 759 (Cal.)

When these vibrational frequencies are compared with the previously reported compounds 
with thiazole [24-29], there are no considerable differences.

\subsubsection{Thiazolidine vibrations}

Fundamental vibrational frequencies of thiazolidine derivatives were reported in a previous study [48]. Since the frequencies of thiazole and thiazolidine are very close to each other, it is currently not possible to assign experimental frequencies to the thiazolidine fragment. However, it can clearly give the calculation results $\left(\mathrm{cm}^{-1}\right)$ :

i. anti-symmetric $\mathrm{C}-\mathrm{H}_{2}$ stretching: 3029 and 3039

ii. symmetric $\mathrm{C}-\mathrm{H}_{2}$ stretching: 2954 and 2962

iii. $\mathrm{C}-\mathrm{H}_{2}$ scissoring: 1418 and 1413

iv. $\mathrm{C}-\mathrm{H}_{2}$ wagging: 1205 and 1211

v. $\mathrm{C}-\mathrm{H}_{2}$ twisting: 1104 and 1110

vi. $\mathrm{C}-\mathrm{S}-\mathrm{C}$ stretching: 775 and 778

\subsubsection{NMR spectra}

The ${ }^{1} \mathrm{H}$ - and ${ }^{13} \mathrm{C}$-NMR spectra and chemical shifts were determined in detail; experimental results were supported by theoretical NMR calculations, with NMR spectra and chemical shifts having been calculated using the Gauge-Independent Atomic Orbital (GIAO) method at the DFT/B3LYP/6-31G(d,p) and DFT/B3LYP/6$31 \mathrm{G}+(\mathrm{d}, \mathrm{p})$ levels in $\mathrm{CDCl}_{3}$ solvent. The ${ }^{1} \mathrm{H}-{ }^{13} \mathrm{C}-$ NMR spectrum of the tetramethylsilane (TMS) molecule was calculated using the same levels, and chemical shifts are converted to the TMS scale by subtracting the calculated absolute chemical shielding of TMS, with values of 31.75 and 192.06 ppm for B3LYP/6-31G(d,p), and 31.64 and 193.08 ppm for B3LYP/6-31G+(d,p), respectively. Figure 7 illustrates the experimental ${ }^{1} \mathrm{H}-($ Fig. $7 \mathrm{a}),{ }^{13} \mathrm{C}-$ (Fig. 7b) and HETCOR (Fig. 7c) NMR spectra of the title compound.

HETCOR is the abbreviation for the HETeronuclear CORrelation spectroscopy, which is the 2D experimental spectrum. Here, heteronuclear connectivity was determined, that is, which ${ }^{1} \mathrm{H}$ is connected to which ${ }^{13} \mathrm{C}$. The chemical shifts obtained from these spectra are presented in Table 6 $\left({ }^{1} \mathrm{H}-\mathrm{NMR}\right)$ and Table $7\left({ }^{13} \mathrm{C}-\mathrm{NMR}\right)$. To enable a comparison with experimental observations, it was calculated the correlation coefficients for B3LYP/6-31G(d,p) and B3LYP/6-31G+(d,p) levels, which are 0.9801 and 0.9771 for ${ }^{1} \mathrm{H}-\mathrm{NMR}$ chemical shifts, 0.9971 and 0.9973 for ${ }^{13} \mathrm{C}-\mathrm{NMR}$ chemical shifts, respectively. According to these correlation values, the B3LYP/6-31G(d,p) method has given good results for ${ }^{1} \mathrm{H}$ NMR while the B3LYP/6-31G+(d,p) method has given good results for ${ }^{13} \mathrm{C}$ NMR. The ${ }^{1} \mathrm{H}$ - and ${ }^{13} \mathrm{C}$ chemical shifts to be obtained from NMR studies are the following:

\subsubsection{1. ${ }^{l} H$ NMR spectra}

The chemical shifts of aromatic protons are observed at about $7 \mathrm{ppm}$ in the ${ }^{1} \mathrm{H}$ NMR spectra, showing that these signals were observed and calculated in the chemical shift range of 6.77-7.11 ppm (Exp.), 6.82-7.48 ppm B3LYP/6-31G(d,p) and 6.96-7.66 ppm B3LYP/6-31G+(d,p). H11A and $\mathrm{H} 12 \mathrm{~A}$ and $\mathrm{H} 11 \mathrm{~B}$ and $\mathrm{H} 12 \mathrm{~B}$ protons cis-related to cyclobutane plane are equivalent and these are in a single peak in ${ }^{1} \mathrm{H}-\mathrm{NMR}$ spectra: $2.05 \mathrm{ppm}$ (H11A and H12A) and $2.17 \mathrm{ppm}$ (H11B and H12B). Also, the $>\mathrm{CH}$ - signal for cyclobutane has been recorded at $3.48 \mathrm{ppm}$ with a J-coupling value of $8.2 \mathrm{~Hz}$. The chemical shift of hydrogen belonging to thiazole was theoretically calculated as 6.60 ppm B3LYP/6-31G(d,p) and 6.90 ppm B3LYP/6$31 \mathrm{G}+(\mathrm{d}, \mathrm{p})$, while this peak was observed at 6.75 $\mathrm{ppm}$ in an experimental spectrum. Thiazolidine $\mathrm{CH}_{2}$ protons have two signals at 3.87 and $4.08 \mathrm{ppm}$ (exp. spectrum), 3.50 and $4.07 \mathrm{ppm}$ (B3LYP/6$31 \mathrm{G}(\mathrm{d}, \mathrm{p})$ ), and 4.02 and $3.53 \mathrm{ppm}$ (B3LYP/6$31 \mathrm{G}+(\mathrm{d}, \mathrm{p}))$.

\subsubsection{2. ${ }^{13}$ C NMR spectra}

${ }^{13} \mathrm{C}$ NMR chemical shifts (with respect to TMS) were calculated in the range from 164.98$20.41 \mathrm{ppm}$ for the B3LYP/6-31G(d,p) level and in the range from $168.70-21.97 \mathrm{ppm}$ for the B3LYP/6-31G+(d,p) level; however, the experimental results were observed to be 170.18-18.56 $\mathrm{ppm}$. The four signals belonging to the cyclobutane ring were at $39.49,41.75,41.32$ and $30.88 \mathrm{ppm}$. $\mathrm{C} 11$ and $\mathrm{C} 12$ carbons are equivalent; however, they have two peaks very close to each other in the ${ }^{13} \mathrm{C}$ NMR spectrum (41.75 and $41.32 \mathrm{ppm}$ ). The chemical shift for the $\mathrm{C}$ atom of the methyl group linked to the cyclobutane ring is observed at 27.78 ppm. There are signals at 107.32 and $155.61 \mathrm{ppm}$ due to $\mathrm{C}$ atoms next to the sulfur atom for thiazole. These signals have been calculated as 110.71, 156.49 and $112.31,159.36 \mathrm{ppm}$ for the B3LYP/6$31 \mathrm{G}(\mathrm{d}, \mathrm{p})$ and B3LYP/6-31+G(d,p) levels, respectively. Similarly, $\mathrm{C}$ atoms next to the sulfur atom for thiazolidine (C18 and C19 carbons) have been observed at 32.90 and 60.31 (exp. spectrum), 36.46 and $67.08 \mathrm{ppm}(\mathrm{B} 3 \mathrm{LYP} / 6-31 \mathrm{G}(\mathrm{d}, \mathrm{p})), 37.07$ and 69.14 ppm (B3LYP/6-31G+(d,p)), respectively. 


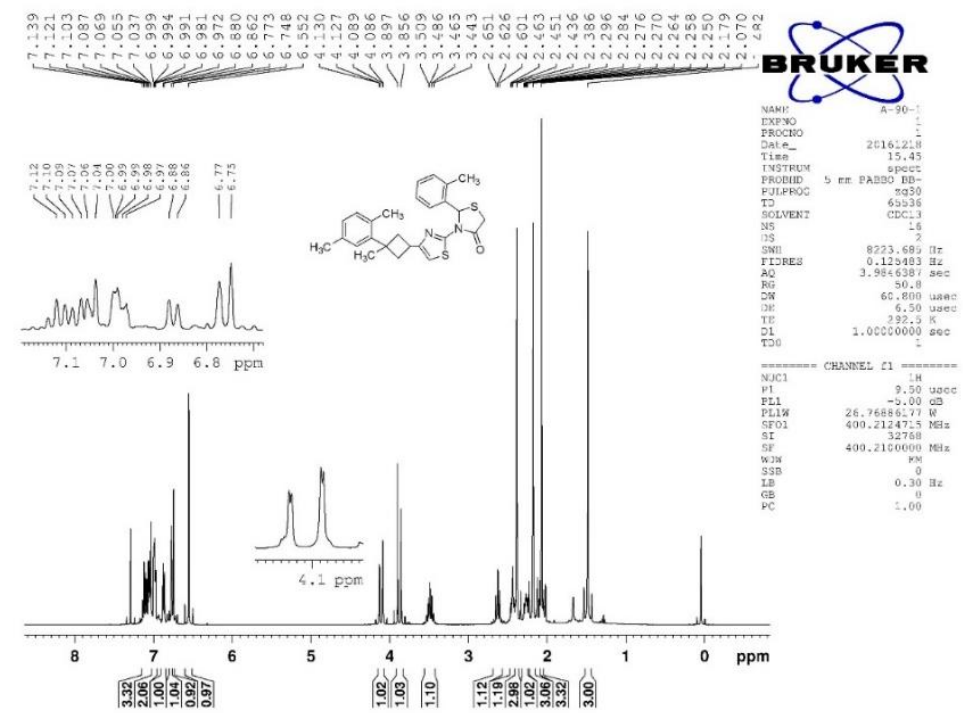

a)

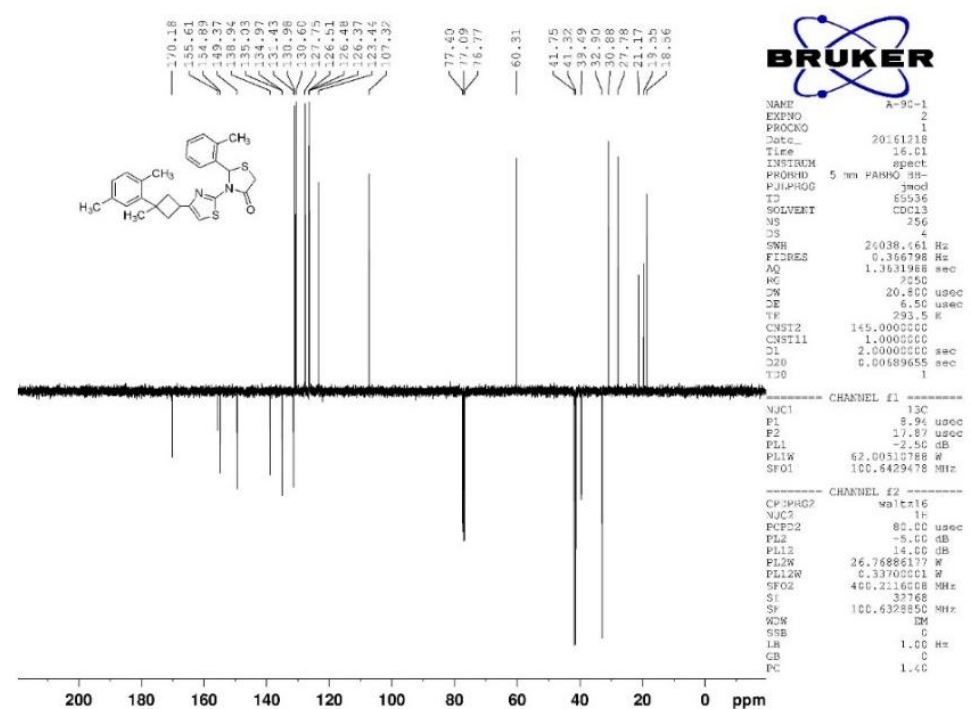

b)

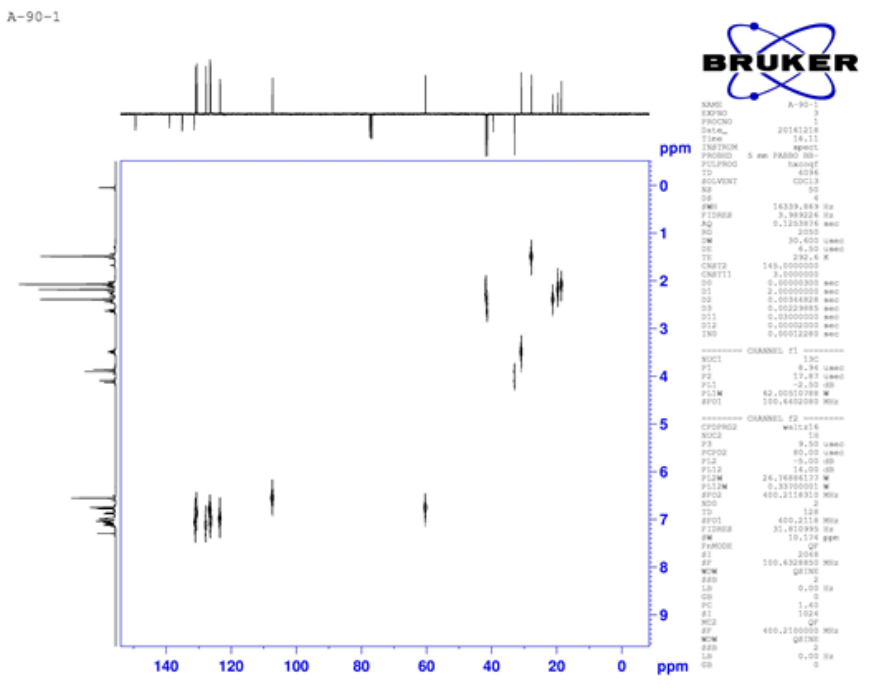

c)

Fig. 7. Nuclear Magnetic Resonance (NMR) spectra of compound in chloroform solvent. a) ${ }^{1} \mathrm{H}-\mathrm{NMR}$, b) ${ }^{13} \mathrm{C}-\mathrm{NMR}$ spectrum (APT), c) Heteronuclear chemical shift correlation (HETCOR) spectrum 
Table 6

Experimental and theoretical ${ }^{1} H$ average isotropic chemical shifts (ppm) for the title compound

\begin{tabular}{cccc}
\hline \hline & & & \multicolumn{2}{c}{$\begin{array}{c}\text { DFT/B3LYP (ppm) } \\
\text { Atom }\end{array}$} & $\begin{array}{c}\text { Experimental } \\
\text { (ppm) }(\mathbf{C D C l})\end{array}$ & \begin{tabular}{c} 
(in CDCl3 solvent) \\
\cline { 3 - 4 }
\end{tabular} & & $\mathbf{6 - 3 1 G ( d , p )}$ & $\mathbf{6 - 3 1 G + ( d , p )}$ \\
\hline H2 & 6.87 & 7.17 & 7.33 \\
H3 & 6.77 & 7.16 & 7.16 \\
H5 & 7.05 & 6.82 & 6.96 \\
H7A & 2.07 & 2.42 & 2.48 \\
H7B & 2.07 & 1.82 & 2.01 \\
H7C & 2.07 & 2.22 & 2.32 \\
H8A & 2.38 & 1.96 & 2.01 \\
H8B & 2.38 & 2.42 & 2.37 \\
H8C & 2.38 & 2.44 & 2.52 \\
H9A & 1.45 & 1.52 & 1.40 \\
H9B & 1.45 & 1.66 & 1.22 \\
H9C & 1,45 & 0.91 & 0.97 \\
H11A & 2.05 & 2.85 & 2.73 \\
H11B & 2.17 & 2.42 & 2.46 \\
H12A & 2.05 & 2.38 & 2.41 \\
H12B & 2.17 & 2.24 & 2.13 \\
H13 & 3.48 & 3.42 & 2.44 \\
H15 & 6.75 & 6.60 & 6.93 \\
H18A & 3.87 & 3.50 & 4.02 \\
H18B & 4.08 & 4.07 & 3.53 \\
H19 & 6.55 & 6.69 & 6.89 \\
H21 & 7.08 & 7.13 & 7.01 \\
H22 & 7.08 & 7.35 & 7.45 \\
H23 & 6.98 & 7.48 & 7.66 \\
H24 & 7.11 & 7.32 & 7.48 \\
H26A & 2.26 & 1.89 & 1.91 \\
H26B & 2.26 & 1.89 & 2.20 \\
H26C & 2.26 & 1.52 & 2.19 \\
\hline \hline & & & \\
\hline
\end{tabular}

\section{CONCLUSIONS}

In conclusion, it was synthesized a novel cyclobutane compound, $\mathrm{C}_{26} \mathrm{H}_{28} \mathrm{~N}_{2} \mathrm{OS}_{2}$, and characterized it using structural (X-ray diffraction) and spectral (FT-IR and NMR) techniques. Furthermore, experimental results were supported and compared with DFT calculations. The $\mathrm{R}^{2}$ correlation coefficients obtained from these comparisons are the following: Structural parameters: 0.9963 and 0.9961 for bond lengths, 0.9954 and 0.9943 for bond angles, 0.9942 and 0.9941 for torsion angles. Also, RMSE values are 0.336 and $0.459 \AA$. Vibrational assignments: 0.999 and $0.9988,{ }^{1} \mathrm{H}-\mathrm{NMR}$ signals: 0.9801 and $0.9771,{ }^{13} \mathrm{C}$ NMR signals: 0.9971 and 0.9973. Both DFT/B3LYP/6-31G(d,p) and DFT/B3LYP/6-31G+(d,p) theoretical methods are in accordance with the experimental findings for the title novel compound.
Table 7

Experimental and theoretical ${ }^{13} \mathrm{C}$ average isotropic chemical shifts (ppm) for the title compound

\begin{tabular}{|c|c|c|c|}
\hline \multirow{2}{*}{ Atom } & \multirow{2}{*}{$\begin{array}{c}\text { Experimental } \\
(\mathbf{p p m})\left(\mathrm{CDCl}_{3}\right)\end{array}$} & \multicolumn{2}{|c|}{ DFT/B3LYP (ppm) } \\
\hline & & 6-31G(d,p) & $6-31 G+(d, p)$ \\
\hline $\mathrm{C} 1$ & 131.43 & 128.56 & 131.23 \\
\hline $\mathrm{C} 2$ & 130.60 & 126.19 & 127.94 \\
\hline $\mathrm{C} 3$ & 126.48 & 121.51 & 123.25 \\
\hline $\mathrm{C} 4$ & 134.97 & 131.32 & 134.16 \\
\hline $\mathrm{C} 5$ & 123.44 & 122.10 & 123.92 \\
\hline C6 & 149.37 & 145.57 & 147.49 \\
\hline $\mathrm{C} 7$ & 19.55 & 21.82 & 23.42 \\
\hline $\mathrm{C} 8$ & 21.17 & 22.14 & 23.11 \\
\hline C9 & 27.78 & 27.98 & 33.10 \\
\hline $\mathrm{C} 10$ & 39.49 & 43.54 & 48.25 \\
\hline $\mathrm{C} 11$ & 41.75 & 42.60 & 44.86 \\
\hline $\mathrm{C} 12$ & 41.32 & 43.10 & 46.71 \\
\hline $\mathrm{C} 13$ & 30.88 & 33.63 & 36.68 \\
\hline $\mathrm{C} 14$ & 154.89 & 148.49 & 151.37 \\
\hline $\mathrm{C} 15$ & 107.32 & 110.71 & 112.31 \\
\hline $\mathrm{C} 16$ & 155.61 & 156.49 & 159.36 \\
\hline $\mathrm{C} 17$ & 170.18 & 164.92 & 168.70 \\
\hline $\mathrm{C} 18$ & 32.90 & 36.46 & 37.37 \\
\hline C19 & 60.31 & 67.08 & 69.14 \\
\hline $\mathrm{C} 20$ & 138.94 & 135.53 & 137.43 \\
\hline $\mathrm{C} 21$ & 127.75 & 117.72 & 122.99 \\
\hline $\mathrm{C} 22$ & 126.37 & 121.63 & 123.68 \\
\hline $\mathrm{C} 23$ & 126.51 & 123.24 & 125.48 \\
\hline $\mathrm{C} 24$ & 130.98 & 125.99 & 128.48 \\
\hline $\mathrm{C} 25$ & 135.03 & 131.85 & 134.94 \\
\hline $\mathrm{C} 26$ & 18.56 & 20.41 & 21.97 \\
\hline
\end{tabular}

Acknowledgments. The authors acknowledge Scientific and Technological Research Application and Research Center, Sinop University, Turkey, for the use of the Bruker D8 QUEST diffractometer. The author thanks Prof. Alaaddin Cukurovali for his supplying crystal as a gift and also assistance in the chemical characterization of the compound. The author thanks Prof. Muharrem Dincer for his supplying DFT calculations.

\section{REFERENCES}

[1] A. Cukurovali, İ. Yilmaz, S. Gur, C. Kazaz, Synthesis, antibacterial and antifungal activity of some new thiazolylhydrazone derivatives containing 3-substituted cyclobutane ring, Eur. J. Med. Chem. 41, 201-207 (2006). DOI: https://doi.org/10.1016/j.ejmech.2005.01.013.

[2] M. Ahmedzade, C. Kirilmis, A. Cukurovali, N. Dilsiz, Synthesis and Antimicrobial Activity of NewThiazole-2(3H)thiones Containing 1,1,3-Trisubstituted Cyclobutane, S. Afr. J. Chem. 56, 21-24 (2003).

[3] M. Y. Cankılıç, L. Yurttaş, Study on the Antimicrobial Effects of Novel Thiazole Derivatives, Marmara Pharm. J. 21, 654-659 (2017). DOI: https://doi.org/10.12991/marupj.323584 
[4] N. U. Guzeldemirci, O. Kucukbasmaci, Synthesis and antimicrobial activity evaluation of new 1,2,4-triazoles and 1,3,4-thiadiazoles bearing imidazo[2,1-b]thiazole moiety, Eur. J. Med. Chem. 45, 63-68 (2010). DOI: https://doi.org/10.1016/j.ejmech.2009.09.024.

[5] O. Bozdağ-Dündar, Ö. Özgen, A. Menteşe, N. Altanlar, O. Atlic, E. Kendi, R. Ertan, Synthesis and antimicrobial activity of some new thiazolyl thiazolidine-2,4-dione derivatives, Bioorg. Med. Chem. 15, 6012-6017 (2007). DOI: https://doi.org/10.1016/j.bmc.2007.06.049

[6] M. Ceylan Unlusoy, O. Bozdağ-Dündar, N. Altanlar, R. Ertan, Synthesis and Antimicrobial Activity of Some New 3-Substituted Benzyl-5-(4-chloro-2-piperidin1ylthiazole-5-yl-methylene)-thiazolidine-2,4-dione Derivatives, Turk. J. Chem. 30, 355-360 (2006).

[7] Y. Song, X. Liu, N. Yang, G. Yang, Synthesis and Antifungal Activity of Some Thiazole Derivatives, Asian J. Chem. 25, 1849-1852 (2013).

[8] V. Opletalova, J. Dolezel, J. Kunes, V. Buchta, M. Vejsova, M. Kucerova-Chlupacova, Synthesis and Antifungal Screening of 2-\{[1-(5-Alkyl/arylalkylpyrazin-2yl)ethylidene]hydrazono\}-1,3-thiazolidin-4-ones, Molecules, 21, 1592 (2016).

DOI: https://doi.org/10.3390/molecules21111592.

[9] A. Ževžikovienè, A. Ževžikovas, E. Tarasevičius, L. Šlepikas, K. Vitkevičius, Synthesis and Antimicrobial Activity of New 3-Allyl-1,3-Thiazolidin-4-Ones, Medicina (Kaunas), 47, 78-84 (2011).

[10] D. Asha, C. V. Kavitha, S. Chandrappa, D. S. Prasanna, K. Vinaya, Sathees C. Raghavan, K. S. Rangappa, Novel Ethyl 2-(1-aminocyclobutyl)-5-(benzoyloxy)-6-hydroxypyrimidine-4-carboxylate Derivatives: Synthesis and Anticancer Activities, J. Cancer Ther. 1, 21-28 (2010). DOI: https://doi.org/10.4236/jct.2010.11003.

[11] W. Cai, A. Liu, Z. Li, W. Dong, X. Liu, N. Sun, Synthesis and Anticancer Activity of Novel Thiazole-5Carboxamide Derivatives, Appl. Sci. 6, 8 (2016). DOI: https://doi.org/10.3390/app6010008.

[12] G. Turan-Zitouni, M. D. Altıntop, A. Ozdemir, Z. A Kaplancıklı, G. A. Çiftçi, Halide E. Temel, Synthesis and evaluation of bis-thiazole derivatives as new anticancer agents, Eur. J. Med. Chem. 107, 288-294 (2016). DOI: https://doi.org/10.1016/j.ejmech.2015.11.002.

[13] T. T Akshaya, V. B Arunlal, Dr. G. Babu, Dr. C. R. Biju., Synthesis, characterisation and invitro anticancer activity of thiazolidine-2,4-dione Derivatives, J. Drug Discov Ther. 2, 42-47 (2014).

[14] Y. Chi, M. Nakamura, X. Zhao, T. Yoshizawa, W. Yan, F. Hashimoto, J. Kinjo, T. Nohara, S. Sakurada, Antinociceptive Activities of $\alpha$-Truxillic Acid and $\beta$-Truxinic Acid Derivatives, Biol. Pharm. Bull. 29, 580-584 (2006). DOI: https://doi.org/10.1248/bpb.29.580

[15] F. A. Hassan, Synthesis, Characterization, Anti-inflammatory, and Antioxidant Activities of Some New Thiazole Derivatives, Int. J. Appl. Sci. Technol. 2, 180-187 (2012).

[16] R. A. Waghmare, M. R. Bhosle, L. D. Khillare, R. A. Mane, Synthesis and Anti-Inflammatory Evaluation of New 5-Arylidene-3- Methylsulphonyl Thiazolidine-2, 4Diones, World J. Pharm Pharm Sci. 4, 1171-1182 (2015).

[17] A. Cukurovali, I. Yilmaz, M. Ahmedzade, Synthesis and Characterization of a New Cyclobutane-Substituted Schiff Base Ligand and its $\mathrm{Co}(\mathrm{II}), \mathrm{Cu}(\mathrm{II})$ and $\mathrm{Ni}(\mathrm{II})$ Complexes, Synth. React. Inorg. Met.-Org. Chem. 30, 843-853 (2000).
DOI: https://doi.org/10.1080/00945710009351803.

[18] I. Yilmaz, A. Cukurovali, Spectral Characterization of a New Cyclobutane and Thiazole Substituted Schiff Base Ligand and Its $\mathrm{Co}(\mathrm{II}), \mathrm{Cu}(\mathrm{II}), \mathrm{Ni}(\mathrm{II})$, and $\mathrm{Zn}$ (II) Complexes, Spectrosc. Lett. 37, 59-72 (2004). DOI: https://doi.org/10.1081/SL-120028423.

[19] K. Dey, S. Sarkar, S. Mukhopadhyay, S. Biswas, Bijali Bikash Bhaumik, Synthesis, characterization and coordination behavior of 2-(1-carboxyl-2-hydroxyphenyl) thiazolidine, J. Coord. Chem. 59, 565-583 (2006). DOI: https://doi.org/10.1080/00958970500358714.

[20] S. Saydam, Synthesis and Characterisation of the New Thiazole Schiff Base 2-(2-Hydroxy) Naphthylideneaminobenzothiazole and Its Complexes with $\mathrm{Co}(\mathrm{Ii}), \mathrm{Cu}(\mathrm{Ii})$, and $\mathrm{Ni}(\mathrm{Ii})$ Ions, Synth. React. Inorg. Met.-Org. Chem. 32, 437-447 (2002). DOI: https://doi.org/10.1081/SIM-120003787.

[21] F. Sen, M. Dincer, A. Cukuroval1, I. Y1lmaz, (Z)-1-(3Mesityl-3-methyl-cyclo-but-yl)-2-(morpholin-4-yl) ethanone oxime, Acta Cryst. E 67, o958-o959 (2011). DOI: https://doi.org/10.1107/S1600536811009408.

[22] F. Sen, M. Dincer, A. Cukuroval1, I. Y1lmaz, 1,1'-Bis(3methyl-3-phenyl-cyclo-but-yl)-2,2'(aza-nedi-yl)diethanol, Acta Cryst. E 68, o1052 (2012). DOI: https://doi.org/10.1107/S1600536812010203.

[23] F. Sen, I. Y1lmaz, M. Dincer, A. Cukuroval1, Structural Features of 2-(4,5-Diphenyl-4h-1,2,4-Triazol-3-Yl)Thio)-1(3-Methyl-3-Phenylcyclobutyl) Ethanone: X-Ray Diffraction and DFT Calculations, J. Chil. Chem. Soc. 60, 26712676 (2015).

DOI: http://dx.doi.org/10.4067/S0717-97072015000400009

[24] F. Sen, I. Yılmaz, M. Dincer, A. Cukurovalı, Experimental (X-ray Diffraction and FT-IR) and Quantum Chemical Studies (HF and DFT) of Ethyl 3-hydroxy-7methyl3-(3-methyl-3-phenylcyclobutyl)-5-phenyl-3,5dihydro-5Hthiazolo [3,2-a]pyrimidine-6-carboxylate, Hacettepe J. Biol. \& Chem. 45, 175-186 (2017). DOI: http://dx.doi.org/10.15671/HJBC.2017.150

[25] F. Sen, O. Ekici, M. Dincer, A. Cukuroval, A comparative study on 4-(4-(3-mesityl-3-methylcyclobutyl)thiazole-2-yl)1-thia-4-azaspiro[4.5]decan-3-one: Experimental and density functional methods, J. Mol. Struct. 1086, 109-117 (2015).

DOI: https://doi.org/10.1016/j.molstruc.2014.12.088

[26] F. Sen, M. Dincer, A. Cukuroval1, I. Y1lmaz, N-[4-(3methyl-3-mesityl-cyclobutyl)-thiazol-2-yl]-succinamic acid: X-ray structure, spectroscopic characterization and quantum chemical computational studies, J. Mol. Struct. 1046, 1-8 (2013).

DOI: https://doi.org/10.1016/j.molstruc.2013.04.039

[27] F. Sen, M. Dincer, A. Cukuroval1, Synthesis, spectroscopic characterization and quantum chemical computational studies on 4-(3-methyl-3-phenylcyclobutyl)-2-(2undecylidenehydrazinyl)thiazole, J. Mol. Struct. 1076, 1-9 (2014).

DOI: https://doi.org/10.1016/j.molstruc.2014.07.041

[28] F. Sen, O. Ekici, M. Dincer, A. Cukuroval1, Spectroscopic and molecular modeling studies of $\mathrm{N}$-(4-(3-methyl-3phenylcyclobutyl)-3-phenylthiazole-2(3H)-ylidene)aniline by using experimental and density functional methods, $J$. Saudi Chem. Soc. 21, 377-389 (2017). DOI: https://doi.org/10.1016/j.jscs.2015.05.004

[29] F. Sen, M. Dincer, A. Cukuroval1, Structural and spectroscopic characterization of 4-(3-methyl-3- 
phenylcyclobutyl)-2-(2-propylidenehydrazinyl)thiazole: A combined experimental and DFT analysis, Spectrochim Acta A 150, 257-267 (2015).

DOI: https://doi.org/10.1016/j.saa.2015.05.079

[30] A. D. Becke, J. Chem. Phys. 98, 5648-5652 (1993). DOI: http://dx.doi.org/10.1063/1.464913

[31] C. Lee, W. Yang, R. G. Parr, Phys. Rev. B 37, 785-789 (1988). DOI: https://doi.org/10.1103/PhysRevB.37.785

[32] G. M. Sheldrick, SHELXS-97; Program for the Solution of Crystal Structures, University of Gottingen, (1997).

[33] G. M. Sheldrick, SHELXL-97; Program for Crystal Structures Refinement, University of Gottingen, (1997).

[34] L. J. Farrugia, WinGX and ORTEP for Windows: an update, J. Appl. Cryst. 45, 849-854 (2012). DOI: https://doi.org/10.1107/S0021889812029111

[35] A. L. Spek, Structure validation in chemical crystallography, Acta Crystallogr. D 65, 148-155 (2009). DOI: https://doi.org/10.1107/S090744490804362X

[36] M. J. Frisch, G. W. Trucks, H. B. Schlegel, G. E. Scuseria, M. A. Robb, J. R. Cheeseman, J. A. Montgomery, Jr., T. Vreven, K. N. Kudin, J. C. Burant, J. M. Millam, S. S. Iyengar, J. Tomasi, V. Barone, B. Mennucci, M. Cossi, G. Scalmani, N. Rega, G.A. Petersson, H. Nakatsuji, M. Hada, M. Ehara, K. Toyota, R. Fukuda, J. Hasegawa, M. Ishida, T. Nakajima, Y. Honda, O. Kitao, H. Nakai, M. Klene, X. Li, J. E. Knox, H. P. Hratchian, J. B. Cross, V. Bakken, C. Adamo, J. Jaramillo, R. Gomperts, R. E. Stratmann, O. Yazyev, A. J. Austin, R. Cammi, C. Pomelli, J. W. Ochterski, P. Y. Ayala, K. Morokuma, G. A. Voth, P. Salvador, J. J. Dannenberg, V. G. Zakrzewski, S. Dapprich, A. D. Daniels, M. C. Strain, O. Farkas, D. K. Malick, A. D. Rabuck, K. Raghavachari, J. B. Foresman, J. V. Ortiz, Q. Cui, A. G. Baboul, S. Clifford, J. Cioslowski, B. B. Stefanov, G. Liu, A. Liashenko, P. Piskorz, I. Komaromi, R. L. Martin, D. J. Fox, T. Keith, M. A. Al-Laham, C. Y. Peng, A. Nanayakkara, M. Challacombe, P. M. W. Gill, B. Johnson, W. Chen, M. W. Wong, C. Gonzalez, J. A. Pople, Gaussian 03, Revision E.01, Gaussian, Inc., Wallingford, CT, (2004).

[37] L. J. Farrugia, ORTEP-3 for Windows - a version of ORTEP-III with a Graphical User Interface (GUI), $J$. Appl. Cryst. 30, 565 (1997). DOI: https://doi.org/10.1107/S0021889897003117

[38] B. Acar, I. Yilmaz, N. Çalıskan, A. Cukurovali, Experimental and theoretical studies of the molecular structure of 7-Methyl-3-[(3-methyl-3-mesityl-cyclobutyl]-5phenyl-5H-thiazolo[3,2- $\alpha$ ]pyrimidine-6-carboxylic acid ethyl ester, J. M. Struct. 1139, 130-136 (2017).
DOI: https://doi.org/10.1016/j.molstruc.2017.03.034

[39] T. Karakurt, A. Cukurovali, N. T. Subasi, I. Kani, Molecular structure and computational studies on 2-((2-)(4(3-(2,5-dimethylphenyl)-3-methylcyclobutyl)thiazol-2yl)hydrazono)methyl)phenol monomer and dimer by DFT calculations, J. M. Struct. 1125, 433-442 (2016). DOI: https://doi.org/10.1016/j.molstruc.2016.07.009

[40] B. Ferah, I. Yılmaz, M. Dincer, A. Cukuroval1, A Comparative Study on 2-(2-benzylidenehydrazinyl)-4-(3-Methyl-3Phenylcyclobutyl) Thiazole: X-Ray, HF and DFT Studies, Anadolu Uni. J. Sci. Techn. B 4, 74-90 (2016). DOI: https://doi.org/10.20290/btdb.37720

[41] B. Ferah, I. Yılmaz, M. Dincer, A. Cukuroval1, Investigation of electronic and molecular properties of 5-(3Methyl-3-Phenylcyclobutyl)-N-Phenyl-3,6-Dihydro-2h1,3,4-Thiadiazin-2-Imine by experimental and theoretical methods, Anadolu Uni. J. Sci. Techn. B 5, 56-69 (2017). DOI: https://doi.org/10.20290/aubtdb.289631

[42] P. B. Sarkar, S. P. Sengupta, Conformations of 4 compounds containing cyclopentane and cyclopentene rings, Z. Kristallogr. 168, 19-23 (1984). DOI: https://doi.org/10.1524/zkri.1984.168.1-4.19

[43] N. Calışkan, C. Dag, M. S. Soylu, A. Cukurovali, N. A. Koksal, 2-Amino-4-(3-methyl-3-p-xylylcyclo-butyl)1,3-thiazole, Acta Cryst. E62, o174-o176 (2006). DOI: https://doi.org/10.1107/S160053680504050X

[44] N. Özdemir, M. Dinçer, A. Çukurovalı, O. Büyükgüngör, Experimental and theoretical investigation of the molecular and electronic structure of 5-(4aminophenyl)-4-(3-methyl-3-phenylcyclobutyl) thiazol2-amine, J. Mol. Model. 15, 1435-1445 (2009). DOI: https://doi.org/10.1007/s00894-009-0509-y

[45] A. P. Scott, L. Radom, Harmonic Vibrational Frequencies: An Evaluation of Hartree-Fock, Møller-Plesset, Quadratic Configuration Interaction, Density Functional Theory, and Semiempirical Scale Factors, J. Phys. Chem. 100, 16502-16513 (1996). DOI: https://doi.org/10.1021/jp960976r

[46] J. P. Merrick, D. Moran, L. Radom, An Evaluation of Harmonic Vibrational Frequency Scale Factors, J. Phys. Chem. A 111, 11683-11700 (2007). DOI: https://doi.org/10.1021/jp073974n

[47] R. Dennington II, T. Keith, J. Millam, Gauss View, Version 4.1.2, Semichem Inc., Shawnee Mission, KS, (2007).

[48] M. Guiliano, G. Mille, T. Avignon, J. Chouteau, Analyse Vibrationnelle de la thiazolidine, J. Raman Spectrosc. 7, 214-224 (1978). DOI: https://doi.org/10.1002/jrs.125007041 